\title{
Effect of Orthodontic Tooth Movement on Salivary Aspartate Aminotransferase Activity
}

\author{
Steiven Adhitya ${ }^{1}$, Janti Sudiono ${ }^{2}$, Joko Kusnoto ${ }^{3}$, Boedi O. Roeslan ${ }^{4}$ \\ ${ }^{1}$ Postgraduate Program, Faculty of Dentisty, Trisakti University, Jakarta 11440, Indonesia \\ ${ }^{2}$ Department of Oral Pathology, Faculty of Dentistry, Trisakti University, Jakarta 11440, Indonesia \\ ${ }^{3}$ Department of Orthodontics, Faculty of Dentistry, Trisakti University, Jakarta 11440, Indonesia \\ ${ }^{4}$ Department of Biochemistry, Faculty of Dentistry, Trisakti University, Jakarta 11440, Indonesia \\ Correspondence e-mail to:steiven adhitya@yahoo.com
}

\begin{abstract}
Aspartate aminotransferase is one of biological indicator in gingival crevicular fluid (CGF). Force orthodontic application could increase activity of aspartate aminotransferase in CGF. However, the increase activity of aspartate aminotransferase in saliva due to orthodontic force and its correlation between aspartate aminotransferase activity and tooth movement remains unclear. Objectives: To evaluate application orthodontic force on the aspartate aminotransferase activity in saliva based on the duration of force and finding correlation between tooth movement and aspartate aminotransferase activity. Methods: Twenty saliva samples collected before extraction of first premolar, at the time of force application for canine retraction and after force application. The canines retraction used 100 grams of interrupted force (module chain) for thirty days. The collection of saliva and the measurement of tooth movement were carried out 1 day, 7 days, 14 days, 21 days, and 28 days after force application. The measurement of aspartate aminotransferase activity in saliva was done using spectrophotometer. Results: Application of orthodontic force influences the salivary aspartate aminotransferase activity $(\mathrm{F}=25.290, p=0.000)$. Furthermore, tooth movement correlated with aspartate aminotransferase activity $(\mathrm{F}=0.429, p=0.000)$. Conclusion: Aspartate aminotransferase activity could be used as tooth movement indicator that related to the duration of force application.
\end{abstract}

\begin{abstract}
ABSTRAK
Efek pergerakan gigi pada perawatan ortodonti pada aktivitas aspartat aminotransferase saliva. Aspartat aminotransferase merupakan salah satu indikator biologis yang dilepaskan ke dalam cairan celah gusi. Aplikasi gaya ortodonti pada gigi dapat meningkatkan aktivitas aspartat aminotransferase dalam cairan celah gusi. Namun peningkatan aktivitas aspartat aminotransferase dalam cairan saliva akibat gaya ortodonti belum diketahui. Tujuan: (1) mengevaluasi durasi pemberian gaya ortodonti terhadap aktivitas aspartat aminotrans- ferase di dalam saliva berdasarkan durasi pemberian gaya. (2) mengevaluasi korelasi jarak pergerakan gigi dengan aktivitas aspartat aminotransferase. Metode: Pengumpulan 20 sampel saliva subjek dilakukan sebelum pencabutan gigi premolar pertama, sebelum dan sesudah pemberian gaya untuk penarikan kaninus ke distal. Penarikan kaninus menggunakan gaya interrupted (module chain) sebesar 100g selama 30 hari. Pengambilan saliva dan pengukuran jarak pergerakan gigi kaninus dilakukan 1 hari, 7 hari, 14 hari, 21 hari, dan 28 hari setelah pemberian gaya. Pengukuran aktivitas aspartat aminotransferase dalam saliva menggunakan alat spektrofotometer. Hasil: Hasil penelitian menunjukkan pemberian gaya ortodonti dapat mempengaruhi aktivitas aspartat aminotransferase dalam saliva $(\mathrm{F}=25,290, p=0,000)$. Jarak pergerakan gigi berkorelasi dengan aktivitas aspartat aminotransferase $(\mathrm{F}=0,429$, $p=0,000)$. Simpulan: aktivitas aspartat aminotransferase dapat digunakan sebagai indikator jarak pergerakan gigi berdasarkan durasi pemberian gaya.
\end{abstract}

Keywords: aspartate aminotransferase, indicator, orthodontic force, tooth movement 


\section{INTRODUCTION}

The application of orthodontic tooth force always involves acute inflammation response. The application of orthodontic force causes a reduction of blood flow in the periodontal ligament reduced and causes a release of inflammatory mediators. Inflammatory mediators will activate osteoclast and osteoblast. The function of osteoclast is to resorp the bone while osteoblast is forming new bone. Activity of osteoclasts and osteoblasts can be detected through biological indicator in gingival crevicular fluid. ${ }^{1-3}$

Aspartate aminotransferase is a biological indicator of tooth movement that released into the gingival crevicular fluid. ${ }^{4}$ Aspartate aminotransferase is an enzyme found in various tissues, this enzyme usually located in the liver and heart. Aspartate aminotransferase found in the cytoplasm and released when cells undergo death..$^{5}$ Trauma on periodontal tissue would stimulate the release of aspartate aminotransferase into gingival crevicular fluid. ${ }^{4}$ Aspartate aminotransferase activity has been used as an indicator for bone remodeling and progression of periodontal disease. ${ }^{6}$ Previous research showed an increase of aspartate aminotransferase activity in gingival crevicular fluid on patient with periodontal disease. ${ }^{7-11}$ One study proved that the increased activity of aspartate aminotransferase also found on patient's saliva. ${ }^{5}$ Several studies in the field of orthodontic have also proved an increase in aspartate aminotransferase activity in the gingival crevicular fluid due to orthodontic force. ${ }^{4,12-14}$ Gingival crevicular fluid collection has limitations because it requires a certain skill to be able to get accurate results. This limitation is due to the small quantity of gingival crevicular fluid and also prone to contamination of the blood.

Saliva is secreted about $600 \mathrm{ml}$ to $1000 \mathrm{ml}$ per day into oral cavity. ${ }^{15}$ Saliva can be used as an indicator of periodontal disease, gingivitis and caries because it contains a variety of enzymes, hormones, antibodies, antimicrobial and growth factors that are similar to blood serum. These components are derived from blood vessels around salivary glands. They secreted into saliva through transcellular process (intracellular passive diffusion and active transport) and paracellular (extracellular ultrafiltration). Therefore they represent the components in the blood serum. ${ }^{16}$ Until now, little is known whether the increase activity of aspartate aminotransferase is related to orthodontic force. Moreover, the correlation between activity of aspartate aminotransferase with tooth movement is unclear. This research aimed to evaluate the effect of orthodontic force application on salivary aspartate aminotransferase activity in relation to orthodontic application and distance of tooth movement.

\section{METHODS}

This was a clinical experimental research consisted of serial observations to determine the effect of orthodontic force on salivary aspartate aminotransferase activity and to examine the correlation between tooth movement and aspartate aminotransferase activity. Twenty orthodontic patients were informed consented to participate in this study voluntarily.

The inclusion criteria were: good oral hygiene, good periodontal tissue and no gingival recession, no bone resorption, extraction of maxilla first premolars and canine retraction are required as part of the orthodontic treatment, agree and sign the informed consent. Twenty saliva samples were collected at several timepoints: before extraction of first premolar, at the time of force application for canine retraction and after force application. The canine retraction was done using 100grams of interrupted force (module chain) for thirty days. The collection of saliva and the measurement of tooth movement was performed at 1, 7, 14, 21 and 28 days after force application (Figure 1, 2). After collection, saliva was stored in $-80^{\circ} \mathrm{C}$ freezer. Salivary aspartate aminotransferase activity was measured by spectrophotometer. Reagent 1 of $1000 \mu \mathrm{L}$ contained Tris buffer pH 7.65 (80mmol/L), L-Aspartate (240mmol/L), MDH ( $\geq 600 \mathrm{U} / \mathrm{L}), \mathrm{LDH}(\geq 900 \mathrm{U} / \mathrm{L})$ was incubated at $37^{\circ} \mathrm{C}$ for 1 min, reagent 2 (2-Oksaloglutarat and $\mathrm{NADH}$ ) and incubated at $37^{\circ} \mathrm{C}$ for also $1 \mathrm{~min}$, added sample of $100 \mu \mathrm{L}$, then activity was measured. Tooth movement was the distance between the distal lateral incisor bracket to the mesial canine bracket before and after force application and was measured using a sliding caliper.

The data was analyzed using Kolmogorov-Smirnov for normality test. Analysis of variance was used to evaluate the effect of the duration of orthodontic force on the salivary aspartate aminotransferase activity and the distance of tooth movement. If there is any significant difference was found, the analysis was continued with multiple comparisons test using HSD Tukey. Pearson correlation test was used to see the correlation between the distance of tooth movement, duration of force application and aspartate aminotransferase activities.

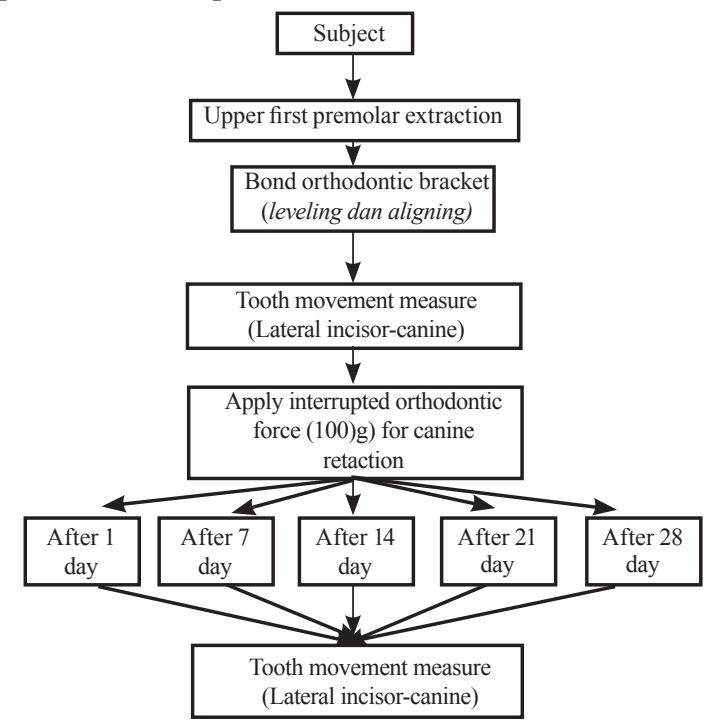

Figure 1. Working diagram for measuring aspartat aminotransferase activity 


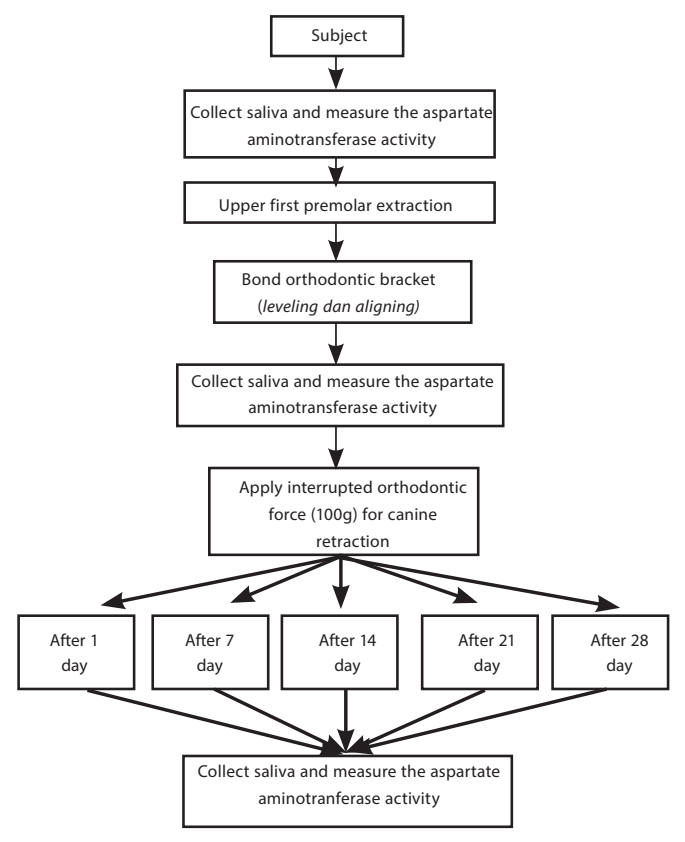

Figure 2. Working diagram for measuring tooth movement

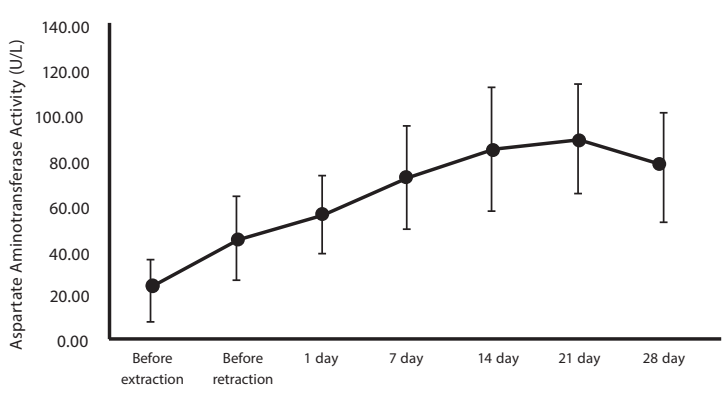

Figure 3. Mean and standard deviation of aspartate aminotransferase activity $(\mathrm{U} / \mathrm{L})$

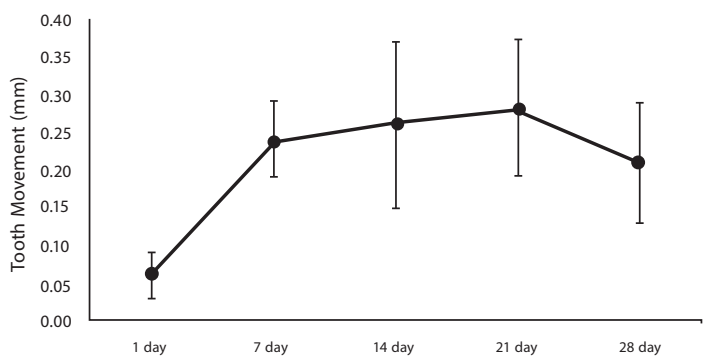

Figure 4. Mean and standard deviation of tooth movement $(\mathrm{mm})$
Table 1. Pearson Correlation between aspartate aminotransferase acitvity, tooth movement and duration of force

\begin{tabular}{cccc}
\hline & Duration & $\begin{array}{c}\text { Tooth } \\
\text { movement }\end{array}$ & AST activity \\
\hline Duration & - & $\mathrm{r}=0.674$ & $\mathrm{r}=0.482$ \\
Tooth movement & $\mathrm{r}=0.674$ & $p=0.000^{*}$ & $p=0.000^{*}$ \\
& $p=0.000^{*}$ & - & $\mathrm{r}=0.472$ \\
AST activity & $\mathrm{r}=0.482$ & $\mathrm{r}=0.472$ & $p=0.000^{*}$ \\
& $p=0.000^{*}$ & $p=0.000^{*}$ & - \\
\hline
\end{tabular}

*significant $=p<0.05$

This study showed that aspartate aminotransferase activities reach its peak in 21 days after application of orthodontic force (Figure 3). Tooth movements reach its peak also in 21 days after the application of orthodontic force (Figure 4). Normality test data by KolmogorovSmirnov showed normal distribution of data. The first hypothesis was to find out whether the duration of force affects the activity of aspartate aminotransferase. This was tested by one-way ANOVA. The result showed that there were significant differences between duration of force with the aspartate aminotransferase activity $(\mathrm{F}=25.290, p=0.000)$ (Table 1).

The next hypothesis was to find out whether the duration of force affects the tooth movement. This was tested by one-way ANOVA. The result showed that there were significant differences between the duration of force with the tooth movement $(\mathrm{F}=54.266$, $p=0.000$ ) (Table 2). The last hypothesis was to find out the correlation between the activity of aspartate aminotransferase, tooth movement and the duration of force. This was tested by Pearson correlation analysis. The result showed that there were correlation among duration of force, tooth movement $(\mathrm{r}=0674$, $p=0.000)$ and aspartate aminotransferase activity $(\mathrm{r}=0482, p=0.000)$. It also showed that aspartate aminotransferase activity correlated with the distance of tooth movement $(\mathrm{r}=0472, p=0.000)$ (Table 1).

\section{DISCUSSION}

The statistical tests showed that the aspartate aminotransferase activity is affected by the duration of orthodontic force. Moreover statistical test results also showed there were significant differences in aspartate aminotransferase activity before and after bracket bonding. The results of the present study was in line with research conducted previously. ${ }^{4}$ The reason 
was due to stimulation of plaque retention at the bracket which cause gingival inflammation.

This research showed that the activity of aspartate aminotransferase increased significantly 7 days after force application. Similar finding was also shown by previous research using gingival crevicular fluid. ${ }^{3,13}$ This could occur because the initial wave of absorption was taken place from 3-5 days after the application of orthodontic force. ${ }^{3,13}$ However, other research showed that the aspartate aminotransferase activity in gingival crevicular fluid increased 14 days after the application of force. ${ }^{12,13}$

The results of statistical tests of this study showed that the duration of orthodontic force affected the distance of tooth movement. Moreover, it showed that tooth movements can be seen 7 days after force application . Furthermore, the peak movement of tooth was at 21 days after force application and after that moment the tooth movement decreased. Previous study stated that the initial wave of resorption occurred at 3-5 days after application of orthodontic force and followed by the opposite at 5-7 days and the final wave of resorption occurred at 7 to 14 days, in line with the data presented in this study. ${ }^{17}$

The average activity of aspartate aminotransferase and tooth movement decreased after 21 days application of force. This might be due to reduction in force because of the force decays from the module chain. ${ }^{18}$ It might probably because healing of tissue around the teeth. Therefore, adjustment of orthodontic appliance should be performed after 21 days application of force.

\section{CONCLUSION}

This study concluded that orthodontic force can increase the activity of aspartate aminotransferase detected in saliva. Furthermore, it also can be concluded that the duration of orthodontic force can increase tooth movement and aspartate aminotransferase activity in saliva. There was a correlation between the activity of aspartate aminotransferase and tooth movement and duration of orthodontic force therefore aspartate aminotransferase can be used as an indicator of the duration of orthodontic force and tooth movement.

\section{ACKNOWLEDGEMENT}

This study was supported by Trisakti University and PUSPITEK (Pusat Penelitian Ilmu Pengetahuan dan Teknologi).

\section{REFERENCES}

1. Roberts WE. Bone physiology, metabolism, and biomechanics in orthodontic practice. In: Graber $\mathrm{TM}$, editors. Orthodontics current principles and techniques. 2nd ed. St. Louis: Mosby; 1994. p. 193-234.

2. Proffit WR. The biology basis of orthodontic therapy. In: Proffit WR, editors. Contemporary orthodontics. 4th ed. St. Louis: Mosby Elsevier; 2007. p.331-58.

3. Perinetti G, Paolantonio M, D’attilio M, D’Archivio D, Dolci M, Femminella B, et al. Aspartate aminotransferase activity in gingival crevicular fluid during orthodontic treatment. A controlled short-term longitudinal study. J Periodontol. 2003;74:145-52.

4. Stolz A, Kaplowitzm N. Biochemical test for liver disease. In: David Z, editors. Hepatology: a textbook of liver disease. 2nd ed. Philadelphia: W.B. Saunders Company; 1989.p.637-67.

5. Todorovic T, Dozic I, Barrero MV, Ljuskovic B, Pejovic J, Marjanovic M, et al. Salivary enzymes and periodontal disease. Med Oral Patol Oral Cir Buccal. 2006;11:115-9.

6. Persson GR, DeRouen TA, Page RC. Relationship between gingival crevicual fluid levels of aspartate aminotransferase and active tissue destruction in treated chronic periodontitis patiens. J Periodont Res. 1990;25:81-7.

7. Persson GR, Page RC. Diagnostic characteristics of crevicular fluid aspartate aminotransferase (AST) levels associated with periodontal disease activity. J Clin Periodontol. 1992;19:43-8.

8. Shimada K, Mizuno T, Uchida T, Kato T, Ito K, Murai S. Relationship between levels of aspartate aminotransferase in gingival crevicular fluid and conventional measures of periodontal status accessed using pocket watch: a cross sectional study. J Oral Sci. 1999;41:35-40.

9. Silva EB, Salvador SLS, Fogo JC, Marcantonio RAC. Use of aspartate aminotransferase in diagnosing periodontal disesase: a comparative study of clinical and microbiological parameters. J Oral Sci. 2003;45:33-8.

10. Totan A, Greabu M, Totan C, Spinu T. Salivary aspartate aminotransferase, alanine aminotransferase and alkaline phosphatase: possible markers in periodontal diseases? Clin Chem Lab Med. 2006;44:612-5.

11. Dannan A, Alkattan F, Hamadeh S, Darwish MA, Sawan MN. Aspartate aminotransferase enzyme activity in gingival crevicular fluid is affected by human orthodontic tooth movement. Orthodontic Cyber Journal [Internet]. 2009 Available from: http://www.orthocj.com/2009/01/aspartateenzyme-activity-in-gingival-crevicular-fluid/.

12. Gunawan E. Aspartate aminotransferase activity 
in canines gingival crevicular fluid during orthodontic movement [thesis]. Jakarta: Trisakti University; 2009.

13. Rohaya MAW, Hisham ZAS, Khazlina K. Preliminary study of aspartate aminotransferase activity in gingival crevicular fluids during orthodontic tooth movement. J Applied Sci. 2009;9:1393-6.

14. Hand AR. 2003. Salivary glands. In: Antonio N, editors. Ten Cate's Oral Histology: Development, atructure, and function. 6th ed. St. Louis: Mosby; 2003. p.299-328.

15. Lee YH, Wong DT. Saliva: an emerging biofluid for early detection of disease. Am J Dent. 2009;22:2418.

16. Keeling SD, King GJ, McCoy EA, Valdez M. serum and alveolar bone phosphatase changes reflect bone turnover during orthodontic tooth movement. Am J Orthod Dentofac Orthop. 1993;103:320-6.

17. Santos ACS, Tortamano A, Naccarato SRF, Dominguez-Rodriguez GC, Vigorito JW. An in vitro comparison of the force decay generated by different commercially available elastomeric chains and NiTi closed coil springs. Braz Oral Res. 2007;21:51-7. 